\title{
OBITUARIES
}

\section{Mr. Cecil Warburton}

Mr. Cecil Warburton died at his home in Grantchester, Cambridge, on October 7 at the age of one hundred and four years and eight months. Although he had lost much of his former physical vigour during the past year or two, he retained to the last his remarkable mental clarity, sense of humour and interest in people and current affairs. Warburton's work as an entomologist and arachnologist was known and respected by several generations of zoologists. His modesty and the charm of his simple and generous personality tended to cloak from those not familiar with his work the solid and enduring value of his scientific achievements.

Cecil Warburton was born on February 6, 1854, at Salford. He was educated at Old Trafford School, Manchester, where he later became second master. $\mathrm{He}$ attended classes at Owens College, Manchester, and took a University of London external B.A. degree. He went to Christ's College, Cambridge, in 1886, read for the Natural Sciences Tripos, graduated B.A. in 1889, and took his M.A. degree in 1892 .

An early interest in spiders directed his zoological studies towards other Arachnida, and mites and ticks later became his main field of study. His knowledge of general zoology was wide, and he was appointed zoologist to the Royal Agricultural Society in 1893, and from that year until 1940 he wrote an annual report for the Society, dealing largely with economic entomology. At first these reports were addressed from the Department of Zoology, Cambridge, but from 1910 until 1940 they came from the School of Agriculture, where he lectured until his retirement in 1932 , thus continuing an association with the teaching of agriculture in the University which had begun as early as 1899-1900 when his name appeared in the list of lecturers for the Board of Agricultural Studies. In 1909 Warburton was the author of Chapters 12-18 of Vol. 4 of the "Cambridge Natural History", which dealt with the Arachnida Embolobranchiata (scorpions, spiders, mites and ticks). This was an important and valuable work, and it provided the background to the fruitful association with G. H. F. Nuttall, then Quick professor at Cambridge, beginning in the Quick Laboratory in 1908, continuing in the Molteno Institute from 1921, and lasting until the death of Nuttall in 1937. It was during this period that his main original contributions were published, dealing with mites and ticks and culminating in the publication, by the Cambridge University Press, of "Ticks; a Monograph of the Ixodoidea", by G. H. F. Nuttall, Cecil Warburton, W. F. Cooper and L. E. Robinson. The first volume was written jointly by G. H. F. Nuttall and Cecil Warburton and comprised: Part 1, "The Argasidae" (1908) ; Part 2, "Ixodidae" (1911); and Part 3, "The Genus Hæmophysalis" (1915).

These studies were of great value to all workers in the rapidly developing subject of ticks as vectors of diseases of man and domestic animals, and they still remain standard works on ticks. Their preparation and publication resulted in a voluminous corre. spondence and the submission of collections of ticks for identification from all parts of the world. Replying to innumerable correspondents and identifying and reporting upon specimens occupied much of the time and energy of both Nuttall and Warburton for many years. Warburton continued identifying and reporting upon specimens of ticks until 1936, when he was eighty-two years of age; and there can be few, if any, collections of ticks in any country in the world which are not enriched by numerous specimens bearing on the label the words "identified by $\mathrm{C}$. Warburton".

He had been appointed University demonstrator in medical entomology by the Quick professor in 1911 , and he retained this post when the Quick Laboratory moved to the Molteno Institute in 1921. Thereafter, until he retired in 1932, his activities were mainly centred on the Institute, and he lectured on parasitic insects and arachnids, and demonstrated to students taking the courses for the diplomas in public health and tropical medicine and hygiene. $\mathrm{He}$ retained a keen interest in the Molteno Institute and those who worked in it to the end, and was an occasional visitor until after his hundredth birthday. Not only did he delight in meeting his old friends there, but also he was always pleased to meet new and younger workers, and all were warmly invited to visit him at his home in Grantchester and play croquet, a game at which he excelled until his sight failed in the last couple of years. He never married. All who knew him will feel they have lost a friend who was warm-hearted, generous and of high integrity both in his private and his scientific life.

P. TATE

\section{Prof. Horace B. Dunnicliff}

THE news of the death on October 8 of Prof. H. B. Dunnicliff was received with great regret in India. Dunnicliff had been intimately associated with the growth of chemical education of the country for the past fifty years. He came out in 1908 as professor of chemistry of the M.A.O. College, Aligarh, where he taught chemistry until the First World War. In 1914, his services were placed at the disposal of the Khalsa College, Amritsar. In 1917, he was on deputation to the Munitions Board and was transferred to the Cordite Factory, Aravankadu. There he stayed until 1921 and did some very useful work. $\mathrm{He}$ was appointed professor of chemistry, Govermment College, Lahore, in 1922. On the reorganization of teaching of the Panjab University he was appointed University professor of inorganic chemistry. Here, a good school of chemistry was soon founded with the help of the late Santiswarup Bhatnagar. Bhatnagar was in charge of the teaching of physical chemistry and Dunnicliff looked after inorganic chemistry.

I was in charge of the organic chemistry section when Dunnicliff joined the Panjab University. The success of the Lahore School of Chemistry was largely due to the untiring efforts of Dunnicliff to keep the ship on an even keel in the stormy communal waters of the Panjab. He had a keen sense of justice and fair play, which kept the University teaching departments free from communal politics. He was seconded to the Government of India in 1928 with the view of organizing the Central Customs Analytical Laboratories. On his return to Lahore in 1929, his Laboratory acted as the appellate laboratory for all 